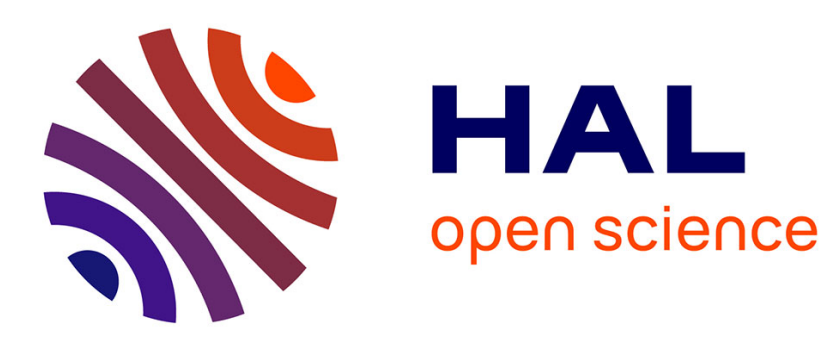

\title{
Expression of clusterin and C4 mRNA during rat peripheral nerve regeneration
}

\author{
Anne-Sophie Bonnard, Philippe Chan, Marc Fontaine
}

\section{To cite this version:}

Anne-Sophie Bonnard, Philippe Chan, Marc Fontaine. Expression of clusterin and C4 mRNA during rat peripheral nerve regeneration. International Immunopharmacology, 1997, 38 (1-2), pp.81-86. 10.1016/S0162-3109(97)00073-8 . cea-02134696

\section{HAL Id: cea-02134696 https://hal-cea.archives-ouvertes.fr/cea-02134696}

Submitted on 20 May 2019

HAL is a multi-disciplinary open access archive for the deposit and dissemination of scientific research documents, whether they are published or not. The documents may come from teaching and research institutions in France or abroad, or from public or private research centers.
L'archive ouverte pluridisciplinaire HAL, est destinée au dépôt et à la diffusion de documents scientifiques de niveau recherche, publiés ou non, émanant des établissements d'enseignement et de recherche français ou étrangers, des laboratoires publics ou privés. 


\title{
Expression of clusterin and $\mathrm{C} 4 \mathrm{mRNA}$ during rat peripheral nerve regeneration
}

\author{
Anne-Sophie Bonnard * Philippe Chan, Marc Fontaine \\ IFRMP No. 23-INSERM U78, 543, Chemin de la Bretèque, BP73, 76233 Bois-Guillaume Cedex, France
}

Received 30 May 1997; accepted 22 July 1997

\begin{abstract}
The complement system (C) is a major piece of the inflammatory processes triggered after tissue injury. Since implication of the $\mathrm{C}$ has been demonstrated during neurodegeneration and Wallerian degeneration, without being clearly explained, we investigated the expression of $\mathrm{C} 4$ and clusterin mRNA, at the lesion site, after rat sciatic nerve crush injury. This pilot study was then realized over 28 days during peripheral nerve regeneration. We determined mRNA expression levels in naive control animals (N) and 2, 7, 14 and 28 days (D) after crush experiment, by using semi-quantitative RT-PCR. We observed a basic constitutive expression of both mRNAs in group N. Clusterin mRNA level increased between D2 and $\mathrm{D} 7$ to reach 2.5-fold the basic level of expression $(\mathrm{N})$ at D7 and D14, and slightly decreased until D28. C4 mRNA underwent a rapid and marked increase and represented 2-3-fold the $\mathrm{N}$ level from D2 to D14, then it decreased until D28 to return to the basic level of expression $(\mathrm{N})$. These preliminary data exhibit very interesting individual variations in mRNA expression and show that a peripheral nerve trauma can stimulate the expression of $\mathrm{C} 4$ and clusterin mRNA at the lesion site. (C) 1997 Elsevier Science B.V.
\end{abstract}

Keywords: Inflammation; C4; Clusterin; Sciatic nerve; Rat

\section{Introduction}

Promoting peripheral nerve regeneration after traumatic injury is yet the major challenge encountered by surgeons and neuroscientists. Many ways

Abbreviations: $\mathrm{C}$, complement system; cDNA, complementary deoxyribonucleic acid; CNS, central nervous system; D, postoperative day; MAC, membrane attack complex; mRNA, messenger ribonucleic acid; PNS, peripheral nervous system; RT-PCR, reverse transcriptase-polymerase chain reaction

* Corresponding author. Present address: Laboratory of Experimental Neurosurgery, Neurosurgery Department, Bicêtre Hospital, 78, Rue du Général Leclerc, 94275 Le Kremlin-Bicêtre Cedex, France. Tel.: + 33-1-45212649; fax: +33-1-45212422. have been explored to enhance axonal regrowth following tissue insult, 'mechanical' ones, like graft or tubular prosthesis, and 'biochemical' ones, consisting in exogenous factor (cellular or molecular) application at the lesion site (Seckel, 1990).

Tissue modifications occurring after peripheral nerve injury have been well documented (Danielsen, 1990), but the role of inflammatory reaction and mainly of its mediators, is still badly understood (Hirschberg et al., 1994; Lu and Richardson, 1991). Among these mediators, produced by inflammatory cells (leukocytes and macrophages), the complement system (C) has an essential role. Indeed, $\mathrm{C}$ activates phagocytosis via macrophage recruitment and opsonization and ends up to cytolysis via the mem- 
brane attack complex (MAC). Moreover, the $\mathrm{C}$ has been demonstrated to act as an effector of demyelinating pathologies (Gay and Esiri, 1991) and one of its regulators, clusterin, is known to be involved in neurodegenerative diseases (McGeer and McGeer, 1992; Rosenberg and Silkensen, 1995). It has already been established that the classical pathway of the $\mathrm{C}$ cascade is activated and clusterin up-regulated, following sensory and motor axon injury (Liu et al., 1995). As regards the $C$ classical pathway activation, Liu et al. (1995) have only inquired about $\mathrm{Cl}$ and $\mathrm{C} 1 \mathrm{q}$ expression, but this pathway consists in $\mathrm{C} 1, \mathrm{C} 2$ and $\mathrm{C} 4$, this latter being one of the most regulated $\mathrm{C}$ factors (Liszewski et al., 1996) and one of the components of $\mathrm{C} 3$ and $\mathrm{C} 5$ convertases. Thus, the dysregulation of $\mathrm{C} 4$ expression could induce non-negligible side effects. The role of clusterin in tissue injury must also be emphasized as it consists in tissue remodelling and setting of injury, including inhibition of the $\mathrm{C}$, lipid recycling, membrane protection and maintenance of cell interactions (Silkensen et al., 1994).

Then, $\mathrm{C}$ and regulators must be considered not only as exerting a degenerative activity but also as triggering repair mechanisms. To go further into the understanding of $\mathrm{C}$ involvement in peripheral nerve regeneration after a trauma, it appears indispensable to know how expression of $\mathrm{C}$ and regulators evolves at the lesion site. The aim of the present study was to investigate, primarily in a simple model of rat sciatic nerve crush, the time course of $\mathrm{C} 4$ and clusterin mRNA expression, using the accurate semi-quantitative RT-PCR method.

\section{Materials and methods}

\subsection{Animals and surgery}

Adult male Sprague-Dawley rats (Charles River, Saint-Aubin lès Elbeuf, France), weighing 350-400 $\mathrm{g}$, were used. Housed two or three to a cage, at a constant temperature of $21 \pm 1^{\circ} \mathrm{C}$, with a photoperiod of $12 \mathrm{~h}$, they had free access to food and water. The rats were anaesthetized by intramuscular injection with a $0.3 \mathrm{ml}$ of ketamine (Imalgène 1000 , Rhône Mérieux, Lyon, France) and $0.3 \mathrm{ml}$ xylazine (Rompum 2\%, Bayer Pharma, Sens, France) cocktail (except non-operated naive animals). Under a surgical microscope and, as far as possible, under aseptic conditions, skin was cut and muscle was opened. Then, the right sciatic nerve was freed from surrounding tissue and crushed, at a midway point between the sciatic notch and the popliteal space, with a hemostatic clamp for $5 \mathrm{~min}$. Superficial wounds were closed in layers (muscle and skin) by standard sutures and animals were allowed to recover in separate cages. Upon regaining consciousness, the animals were returned to their cage and allowed free access to food and water until sacrifice. This procedure was in agreement with French laws concerning animal experimentation.

\subsection{Total RNAs preparation}

Expression of $\mathrm{C} 4$ and clusterin genes was examined in sciatic nerve samples taken from naive control animals (N) and 2, 7, 14, 28 days (D) following surgery. At times of sacrifice, rats were anaesthetized with the same ketamine/xylazine cocktail as for surgery, both ipsilateral and contralateral sciatic nerves were exposed and quickly removed, placed in a sterile microcentrifuge tube and frozen in liquid nitrogen before storage at $-70^{\circ} \mathrm{C}$ until use. Total RNAs were extracted from the sciatic nerves with the RNA QUICK ${ }^{\text {TM }}$ II kit (Bioprobe Systems, Montreuil, France) according to the manufacturer instructions. RNA concentrations were determined from the absorbance at $260 \mathrm{~nm}$. RNA integrity was controlled by visualization of the $18 \mathrm{~S}$ and $28 \mathrm{~S}$ ribosomal bands after ethidium bromide staining in $1 \%$ agarose gels. The RNA were stored at $-70^{\circ} \mathrm{C}$ until use.

\subsection{Semi-quantitative reverse transcriptase-poly- merase chain reaction ( $R T-P C R$ )}

\subsection{1. $R T$}

cDNA synthesis was performed with constant amounts of total RNAs $(1.5 \mu \mathrm{g})$, containing $\beta$-actin (endogenous internal standard). Prior to PCR steps, the RT was carried out for $60 \mathrm{~min}$ at $37^{\circ} \mathrm{C}$ in $30 \mu \mathrm{l}$ (final volume) with $1.5 \mu \mathrm{g}$ of total RNAs, $30 \mathrm{U}$ RNAsin (Promega, Charbonnière, France), 250 pmol random hexamer primers (pdN6 from Pharmacia Biotech, Orsay, France), 5 mM DTT (Life Technolo- 
gies, Cergy-Pontoise, France) and $200 \mathrm{U}$ murine Moloney leukaemia virus (M-MLV) RT (Life Technologies) in the reaction buffer ( $50 \mathrm{mM}$ Tris- $\mathrm{HCl}, 75$ $\mathrm{mM} \mathrm{KCl}$ and $3 \mathrm{mM} \mathrm{MgCl}_{2}$ ). The cDNA obtained were stored at $-20^{\circ} \mathrm{C}$.

\subsubsection{PCR}

PCR was carried out with $7 \mu \mathrm{l}$ of cDNA mixture, in $100 \mu \mathrm{l}$ final reaction with $2.5 \mathrm{mM} \mathrm{MgCl}{ }_{2}$ (Promega), $200 \mu \mathrm{M}$ dNTPs (Pharmacia), 50 pmol ( $\beta$ actin primers) to 250 pmol (clusterin and $C 4$ primers) of specific primers (Bioprobe Systems, see Section 2.4) and 2.5 U Taq DNA polymerase (Promega) in the reaction buffer $(50 \mathrm{mM} \mathrm{KCl}, 10 \mathrm{mM}$ Tris- $\mathrm{HCl}$, $\mathrm{pH}=9$, and $0.1 \%$ Triton X-100). PCR parameters were: denaturation step for $3 \mathrm{~min}$ at $94^{\circ} \mathrm{C} ; 5$ cycles $\left(94^{\circ} \mathrm{C}, 40 \mathrm{~s} ; 57^{\circ} \mathrm{C}\right.$ (clusterin) or $59^{\circ} \mathrm{C}(\mathrm{C} 4), 50 \mathrm{~s}$; $\left.72^{\circ} \mathrm{C}, 1 \mathrm{~min}\right)$ with ramping $\left(6 \mathrm{~s} /{ }^{\circ} \mathrm{C}\right.$, from annealing temperature to $\left.72^{\circ} \mathrm{C}\right) ; 21$ cycles without ramping; last elongation step $\left(72^{\circ} \mathrm{C}, 10 \mathrm{~min}\right) . \mathrm{PCR}$ was performed in a Hybaid Omnigene thermocycler (Schleicher and Schuell, Céra-Labo, Ecquevilly, France). PCR products were stored at $+4^{\circ} \mathrm{C}$. The absence of contaminant was routinely checked by PCR on negative control samples in which either RNA were replaced with sterile water before PCR, or M-MLV RT was omitted before RT. As expected, no non-specific amplification products were observed at the size of studied factors. Amplicon sizes were 535 bases pairs (bp), 252 bp and 258 bp respectively for $\beta$-actin, clusterin and $\mathrm{C} 4$.

\subsection{Probes}

Specific probes were cloned from rat monocytes ( $\beta$-actin), rat testis (clusterin) and rat liver (C4) total RNAs, by RT-PCR with the following specific primers $\left(5^{\prime}-3^{\prime}\right.$ orientation): $\beta$-actin (EMBL V01217) 5'-CAGAGCAAGAGAATCCT, 3'-GGCAGCTCRTAGCTCTTCTC; clusterin (EMBL M16975) 5'TCTCWGACAATGAGCTCCA, 3'-CAGAGGGCCATCATGGCTT; C4 (EMBL K02403 and EMBL M11729) 5'-CGGGTCTTTGCWCTGGATCA, 3'CTTCACCTCRAAGTTGGGAA. cDNAs were purified on agarose gel using the Jet Sorb DNA Extraction kit (Genomed, Bioprobe Systems) and subcloned in the pGEM-T ${ }^{\mathrm{TM}}$ Vector (Promega). Plasmids were used to transfect $E$. coli $\mathrm{DH} 5 \alpha$, by electroporation (Easyject + , Eurogentec, Belgium) and recombinant clones were identified by blue/white screening. Identity and orientation of inserts were checked by dideoxy sequencing at both ends using primers for pUC-based plasmids (Boehringer Mannheim, Meylan, France), [ $\left.\alpha^{33} \mathrm{P}\right]$-dATP (3000 Ci/mmol, Isotopchim, Ganagobie-Peyruis, France) and a T7 polymerase sequencing kit (Pharmacia). The sequencing reactions were separated onto buffer-gradient gel, sequences were compared to rat sequences in DNASIS Software (Pharmacia), and found to be analogous to these latters.

Specific cDNA probes were prepared by PCR from positive clones and purified on agarose gel with the same procedure described above. For Southern blotting, probes were labelled by the random oligo procedure with $\left[\alpha^{32} \mathrm{P}\right]$-dCTP $(3000 \mathrm{Ci} / \mathrm{mmol}$, Amersham, Les Ulis, France), and had a specific activity of 0.5 to $2 \times 10^{9} \mathrm{cpm} / \mathrm{mg}$.

\subsection{Southern blots}

Southern blotting was performed by way of migration of $7 \mu 1$ of RT-PCR products. After slight staining with ethidium bromide, the gel was treated $30 \mathrm{~min}$ in $0.4 \mathrm{NaOH}$ and Southern blotting was realized in $0.4 \mathrm{NaOH}$ with a vacuum apparatus (Vacugene ${ }^{\mathrm{rM}} \mathrm{XL}$, Pharmacia) onto Nylon membranes (Hybond $\mathrm{N}+$, Amersham). Pre-hybridization (3 to 4 $\mathrm{h}, 42^{\circ} \mathrm{C}$ ) and hybridization $\left(16\right.$ to $20 \mathrm{~h}, 42^{\circ} \mathrm{C}$ ) were done in a hybridization oven at high stringency: $50 \%$ deionized formamide; $5 \times$ SSPE $(150 \mathrm{mM} \mathrm{NaCl}, 10$ $\mathrm{mM} \mathrm{NaH} \mathrm{PO}_{4}, 1 \mathrm{mM}$ EDTA, $\mathrm{pH}=7.4$ ); $5 \times$ Denhardt's reagent; $1 \%$ SDS; $5 \%$ dextran sulphate; and $100 \mu \mathrm{g} / \mathrm{ml}$ denatured and fragmented herring sperm DNA. Post-hybridization washings were done in: $2 \times$ SSPE, $0.1 \%$ SDS, four times at room temperature; $2 \times$ SSPE, $0.1 \%$ SDS, for $1 \mathrm{~h}$ at $68^{\circ} \mathrm{C} ; 1 \times$ SSPE, $0.1 \%$ SDS, for $1 \mathrm{~h}$ at $68^{\circ} \mathrm{C}$. Autoradiographic exposures were performed onto Cronex 4 films (Dupont-NEN, Les Ulis, France) for a time ranging from $30 \mathrm{~min}$ to $1 \mathrm{~h}$.

\subsection{Semi-quantitative analysis of amplification products}

Semi-quantitative analysis was performed using Lecphor 2.0 software (Biocom Image Station, Biocom, Les Ulis, France) to estimate intensity of signals featuring either standard ( $\beta$-actin) or target 
(clusterin or C4) mRNA (Fig. 1). Values of target mRNA expression were calculated as follows: for each group, image analysis gave two series of values, one for standard and the other one for target mRNA ( 3 or 4 values per group); each target value was corrected for the difference of percentage between its corresponding standard value and the mean standard value (standard values are considered not to vary during all the experiment). Mean $\pm S D$ was calculated for each group (N, D2, D7, D14, D28), and reported on graphics, as relative units, as function of surgical groups.

\subsection{Statistical analysis}

Statistical analysis of the data was performed by ANOVA and Fisher's PLSD $F$ test using StatView $512+{ }^{\mathrm{TM}} 1.0$ software for Macintosh.

\section{Results}

\subsection{Semi-quantitative RT-PCR optimization}

During RT and PCR, manipulation variations can be corrected by performing a coamplification of the factor of interest with an endogenous internal standard (which expression is considered as constant and constitutive) or an exogenous internal standard (which expression is fixed up by introducing the same quantity of its RNA in all samples before performing RT) (Dukas et al., 1993). Competition between standard and target templates during PCR implies many trials to determine optimal primer ratio
(1/5), amplification cycle number (16) and annealing temperature $\left(57^{\circ} \mathrm{C}\right.$ and $\left.59^{\circ} \mathrm{C}\right)$, so as to obtain uniform coamplification (data not shown). The optimal number of PCR cycles allows the quantification of amplification products while remaining in the exponential amplification zone, beneath the 'plateau phase' (Morrison and Gannon, 1994). PCR primers were chosen, whenever it was possible, at splice junction on the RNA or DNA sequence or in two different exons, respectively to avoid or recognize genomic amplification products. Each couple of primers was specific for each studied factor, $\mathrm{A} / \mathrm{T}$ and $\mathrm{G} / \mathrm{C}$ contents were approximately equivalent to have similar $\mathrm{Tm}$ for $5^{\prime}$ and $3^{\prime}$ primers, and finally complementary sequences in primers were avoided to impede dimer formation and artefactual amplifications.

\subsection{Clusterin mRNA (Fig. 2A) and C4 mRNA (Fig. $2 B$ ) expression}

For both factors, we observed a constitutive mRNA expression at a low but notable level, since we detected signals in both $\mathrm{N}$ groups.

Clusterin mRNA expression began to increase after D2. It reached a maximum of expression at D7-D14, that represented 2.5-fold the $\mathrm{N}$ level. Then, although the D28 mean \pm S.D. was not significantly different from the $\mathrm{N}$ one, it seamed that clusterin mRNA expression decreased from D14 to D28, to a level still higher than the $\mathrm{N}$ one.

Compared to clusterin, C4 mRNA expression underwent an earlier increase, that occurred before D2.
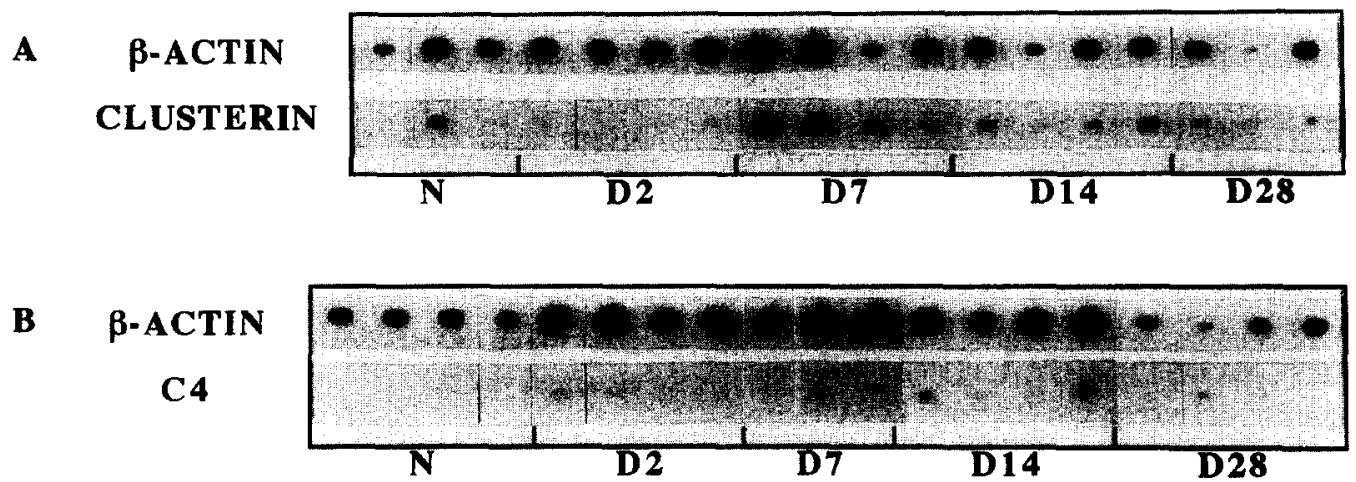

Fig. 1. Southern blots representing the co-expression of $\beta$-actin/clusterin (A) and $\beta$-actin/C4 (B) mRNA in sciatic nerves of adult rats: naive control animals (N) and 2 (D2), 7 (D7), 14 (D14), 28 (D28) days after crush injury, $\beta$-actin mRNA was used as an endogenous internal standard for both semi-quantitative RT-PCR experiments. $n=3$ or 4 animals per group. 

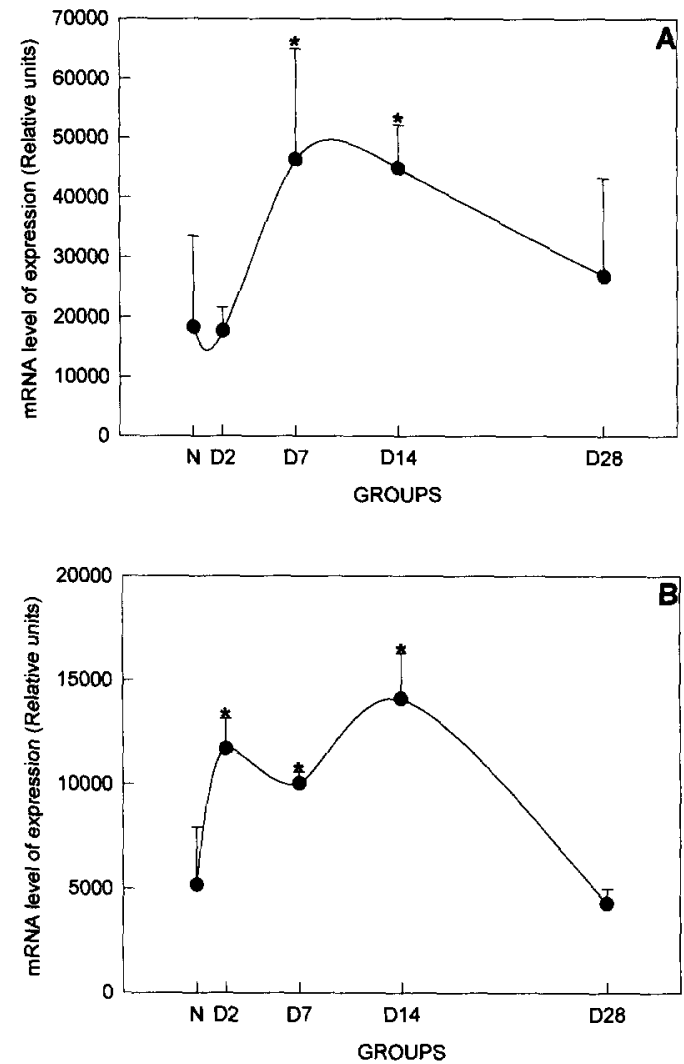

Fig. 2. Graphic representation of clusterin (A) and C4 (B) mRNA expression in sciatic nerves of adult rats: naive control animals (N) and 2 (D2), 7 (D7), 14 (D14), 28 (D28) days after crush injury. Quantification of values was done by scanning autoradiographies of Southern blots (presented in Fig. 1). Each value of clusterin or $\mathrm{C} 4 \mathrm{mRNA}$ expression was corrected for the difference of percentage between its corresponding $\beta$-actin value and the mean $\beta$-actin value (for details, see Section 2). Means \pm S.D. were calculated at each time, and are represented on two distinct scales because of the differences between clusterin and C4 mRNA levels of expression. ANOVA analysis of variance ( $F$ clusterin $=4.3, F$ $\mathrm{C} 4=21.8)$ and Fisher's $F$ test $(p<0.05)$ were performed. (A) (*) versus $\mathrm{N}$ and $\mathrm{D} 2$ groups. (B) $(*)$ versus $\mathrm{N}$ group.

At D2, D7 and D14, C4 mRNA expression remained at a high level, representing respectively $2.5-, 2-$ and 3-fold the basic level of expression (N). Then it decreased progressively to reach back the $\mathrm{N}$ level of expression between D14 and D28.

\section{Discussion}

In this study, we demonstrate that both clusterin and C4 mRNAs are constitutively expressed and increased at the lesion site following rat sciatic nerve crush. Indeed, clusterin mRNA expression reaches a maximum at D7-D14, and C4 mRNA expression at D2-D14.

Liu et al. (1995) provided evidence for C classical pathway and regulator activation after sciatic nerve transection. They observed an increase of $\mathrm{C} 1$ and $\mathrm{C} 1 \mathrm{q}$ immunoreactivity as soon as D2, which remained high until D28. These authors also demonstrated the up-regulation of clusterin mRNA from D2 to D7, and of clusterin immunoreactivity from D2 to D28. The slight discrepancies observed at D2 and D28 could be explained by the fact that their experiments were carried out in the spinal cord, after sciatic nerve transection, and by other technical approaches. Our results confirm and extend this study, since we demonstrate a markedly enhanced $\mathrm{C} 4$ mRNA expression at the crush site, which strengthens the hypothesis of $\mathrm{C}$ classical pathway activation.

Following a peripheral nerve injury, regeneration cannot occur properly if Wallerian degeneration is not achieved (Beuche and Friede, 1984; Dahlin, 1995; Perry et al., 1987). Macrophage recruitment and myelin debris phagocytosis are critical processes, as they clear the way for proliferating Schwann cells, which are the main support for spontaneously regenerating peripheral axons. Previous studies, realized in our laboratory, have demonstrated that microglial cells and astrocytes are both able to synthesize all the $\mathrm{C}$ components as well as clusterin (Gasque et al., 1992, 1993, 1995). By analogy with CNS cells, we could postulate that Schwann cells, participating to the PNS scaffold tissue like astrocytes in the CNS, and macrophages recruited at the lesion site represent the best candidates to assume the production of $\mathrm{C}$ components and clusterin.

We observed that the stimulation of $\mathrm{C} 4$ mRNA expression started earlier than the clusterin one. That could support the idea that the activation of $\mathrm{C}$ cascade plays a role in Wallerian degeneration, mainly by stimulating macrophage recruitment (anaphylatoxins) and myelin phagocytosis (opsonization). Schwann cells could also participate to this step, since they are able to exert a phagocytic activity (Fernandez-Valle et al., 1995; Reichert et al., 1994).

Moreover, the delayed expression of clusterin mRNA could be emphasized by its functions in the regulation of the $\mathrm{C}$ terminal pathway and in tissue 
remodelling (Rosenberg and Silkensen, 1995; Silkensen et al., 1994). On the one hand, clusterin is considered as an inhibitor of the MAC formation and subsequently of the C-mediated cytolysis. On the other hand, clusterin is involved in lipid recycling, membrane protection and maintenance of cell-cell or cell-substratum interactions. The combination of these effects leads us to think that clusterin production at the lesion site could provide a favorable environment to Schwann cell proliferation and axonal regrowth.

This pilot work on $\mathrm{C} 4$ and clusterin expression at the site of the crush injury needs obviously to be further investigated. Determination of the time course of other $\mathrm{C}$ components and regulators expression has to be achieved as well as the identification of their cellular sources. Furthermore, it would be very interesting to inquire about the in situ effects of the administration of $\mathrm{C}$ components and regulators, at the lesion site. For instance, using a model of peripheral nerve regeneration through a tubular prosthesis (Seckel, 1990) would be greatly valuable to point out neuroprotective or neurodestructive effects of inflammatory mediators mainly recognized yet for their immune properties.

\section{Acknowledgements}

The authors would like to address very special thanks to Dr. N. Bodjarian for precious help in the editing of the manuscript.

\section{References}

Beuche, W., Friede, R.L., 1984. The role of non-resident cells in Wallerian degeneration. J. Neurocytol. 13, 767-796.

Dahlin, L.B., 1995. Prevention of macrophage invasion impairs regeneration in nerve grafts. Brain Res. 679, 274-280.

Danielsen, N., 1990. Regeneration of the rat sciatic nerve in the silicone chamber model. Restor. Neurol. Neurosci. 1, 253-259.

Dukas, K., Sarfati, P., Vaysse, N., Pradayrol, L., 1993. Quantification of changes in the expression of multiple genes by simultaneous polymerase chain reaction. Anal. Biochem. 215, 66-72.

Fernandez-Valle, C., Bunge, R.P., Bunge, M.B., 1995. Schwann cells degrade myelin and proliferate in the absence of macrophages: evidence from in vitro studies of Wallerian degeneration. J. Neurocytol. 24, 667-679.

Gasque, P., Fontaine, M., Morgan, B.P., 1995. Complement expression in human brain. Biosynthesis of terminal pathway components and regulators in human glial cells and cell lines. J. Immunol. 154, 4726-4733.

Gasque, P., Julen, N., Ischenko, A., Picot, C., Mauger, C., Chauzy, C., Ripoche, J., Fontaine, M., 1992. Expression of complement components of the alternative pathway by glioma cell lines. J. Immunol. 149, 1381-1387.

Gasque, P., Ischenko, A., Legoedec, J., Mauger, C., Schouft, M.T., Fontaine, M., 1993. Expression of complement classical pathway by human glioma in culture. A model for complement expression by nerve cells. J. Biol. Chem. 268, 2506825074.

Gay, D., Esiri, M., 1991. Blood-brain barrier damage in acute multiple sclerosis plaques. An immunocytological study. Brain 114, 557-572.

Hirschberg, D.L., Yoles, E., Belkin, M., Schwartz, M., 1994. Inflammation after axonal injury has conflicting consequences for recovery of function: rescue of spared axons is impaired but regeneration is supported. J. Neuroimmunol. 50, 9-16.

Liszewski, M.K., Farries, T.C., Lublin, D.M., Rooney, I.A.. Atkinson, J.P., 1996. Control of the complement system. Adv. Immunol. 61, 201-283.

Liu, L., Törnqvist, E., Mattsson, P., Eriksson, N.P., Persson, J.K.E., Morgan, B.P., Aldskogius, H., Svensson, M., 1995. Complement and clusterin in the spinal cord dorsal horn and gracile nucleus following sciatic nerve injury in the adult rat. Neuroscience 68, 167-179.

Lu, X., Richardson, P.M., 1991. Inflammation near the nerve cell body enhances axonal regeneration. J. Neurosci. 11, 972-978.

McGeer, P.L., McGeer, E.G., 1992. Complement proteins and complement inhibitors in Alzheimer's disease. Res. Immunol. $143,621-623$.

Morrison, C., Gannon, F., 1994. The impact of the PCR plateau phase on quantitative PCR. Biochim. Biophys. Acta 1219, $493-498$

Perry, V.H., Brown, M.C., Gordon, S., 1987. The macrophage response to central and peripheral nerve injury: a possible role for macrophages in regeneration. J. Exp. Med. 165, 1218 1223.

Reichert, F., Saada, A., Rotshenker, S., 1994. Peripheral nerve injury induces Schwann cells to express two macrophage phenotypes: phagocytosis and the galactose-specific lectin MAC-2. J. Neurosci. 14, 3231-3245.

Rosenberg, M.E., Silkensen, J., 1995. Clusterin: physiologic and pathophysiologic considerations. Int. J. Biochem. Cell Biol. $27,633-645$.

Seckel, B.R., 1990. Enhancement of peripheral nerve regeneration. Muscle Nerve 13, 785-800.

Silkensen, J.R., Schwochau, G.B., Rosenberg, M.E., 1994. The role of clusterin in tissue injury. Biochem. Cell Biol. 72. $483-488$ 